\title{
Pembinaan Remaja Masjid dalam Mempelajari Al-Quran
}

\author{
*Moh Sain ${ }^{1)}$, Asmariani' ${ }^{2)}$, Ahmad ${ }^{3)}$, Seriyanti Siagian ${ }^{4)}$ \\ ${ }^{1)}$ Program Studi PAI STAI Auliaurrasyidin Tembilahan, Indragiri Hilir, Riau, Indonesia \\ ${ }^{2)}$ Program Studi MPI, Universitas Islam Indragiri, Indragiri Hilir, Riau, Indonesia \\ ${ }^{3)}$ Program Studi Pendidikan Bahasa Inggris Universitas Islam Indragiri, Indragiri Hilir, Riau, Indonesia \\ ${ }^{4)}$ Program Studi Ekonomi Syariah, STAI Auliaurrasyidin Tembilahan, Indragiri Hilir, Riau, Indonesia \\ Email: moh.sain@stai-tbh.ac.id'; ; asmariani@unisi.ac.id²; ahmadfkipunisi@gmail.com³ \\ tbh.ac.id ${ }^{4}$
}

Cara Mensitasi Artikel ini:

Sain, M., Asmariani, A., Ahmad, A., \& Siagian, S. Y. (2021). Pembinaan remaja Masjid dalam mempelajari AlQuran. ABDIMASY: Jurnal Pengabdian dan Pemberdayaan Masyarakat, 2(1), 19-24. https://doi.org/10.46963/ams.v2i1.333

\section{Sejarah Artikel}

Diterima : :01/06/2021

Direvisi : :05/06/2021

Diterbitkan : 29/06/2021

*) Corresponding Author

moh.sain@stai-tbh.ac.id

\section{DOI}

https://doi.org/10.46963/ams.v2i1.333

\section{Kata Kunci:}

Pembinaan; Remaja; Al-Quran

Keywords:

Youth; Guidance; Al-Quran

\section{Editorial Address}

Kampus Panam (Parit Enam) STAI Auliaurrasyidin, Jl. Gerilya No. 12 Tembilahan Barat, Riau, Indonesia, 29213 abdimasy@stai-tbh.ac.id
Abstract: One of the public concerns at Parit. 17 Sungai Beringin, Tembilahan Sub-district, Indragiri Hilir, the Ar-Rahman Mosque held guidance for learning Al-Quran using the tazkirah method. The guidance of the Al-Quran aimed to make the youth the holder of control in prospering and developing programs that have been designed by the administrators or founders of the previous mosque. The youth are a group of human beings full of potential who need to be guided and directed, without being guided and directed, meaning breaking the chain of relay holders to leaders to function the mosque as a means of da'wah and other places of study of Islamic knowledge.

Abstrak: Salah satu bentuk kepedulian masyarakat Parit. 17 Kelurahan Sungai Beringin Kelurahan Sungai Beringin Kecamatan Tembilahan kabupaten Indragiri hilir, Masjid ArRahman mengadakan pembinaan pembelajaran Al-Quran dengan metode tazkirah. Pembinaan Al-Quran tersebut bertujuan menjadikan remaja masjid sebagai pemegang kendali dalam memakmurkan dan mengembangkan program-program yang telah dirancang oleh para pengurus atau pendiri masjid sebelumnya. Remaja adalah kelompok manusia yang penuh potensi, yang perlu digerakkan dan diarahkan, tanpa diarahkan dan digerakkan berarti memutuskan mata rantai pemangku estafet ke pemimpin dalam rangka memfungsikan masjid sebagai sarana dakwah serta tempat pengkajian ilmu keislaman lainnya.

(c) (1) This work is licensed under a Creative Commons Attribution-ShareAlike 4.0 International License (CC-BY-SA)

\section{PENDAHULUAN}

Pada awalnya perkembangan dimasa Rasulullah Muhammad SAW, Masjid menjadi bagian tak terpisahkan dari perkembangan agama Islam. Masjid menjadi pusat dari perkembangan Islam sendiri. (hadi Pada masa awal perkembangan Islam di nusantara pun, tidak terlepas dari pengoptimalannya peran dan pungsi masjid tersebut. Hal terlihat dengan banyaknya Masjid-masjid kuno yang terdapat di berbagai pelosok nusantara yang masih terpelihara dengan baik, dan dianggap sebagai warisan kebudayaan Islam. Antara lain Masjid Agung Demak, Masjid Sunan Ampel, 
Masjid Sunan Kudus, dan lain sebagainya. Hingga akhirnya di setiap desa didirikan sebuah Masjid yang disebut Masjid desa dikarenakan pentingnya keberadaan Masjid itu sendiri dalam penyebaran agama Islam.

Masjid pada masa kini telah berubah, sehingga timbullah lembaga-lembaga baru yang mengambil alih sebagian peranan Masjid di masa lalu, yaitu organisasi-organisasi keagamaan swasta dan lembaga-lembaga pemerintah, sebagai pengaruh kehidupan duniawi umat beragama. Lembaga-lembaga itu memiliki kemampuan material dan teknis melebihi masjid. Fungsi dan peranan masjid besar yang disebutkan pada masa keemasan Islam itu tentunya sulit diwujudkan pada masa kini. Namun, ini tidak bahwa masjid tidak dapat berperan di dalam hal-hal tersebut.

Karena mengembalikan citra masjid masa lalu akan dimulai mengadakan pembinaan dan pengajaran Al-Quran bagi remaja di masjid Ar-Rahman ini dikarenakan remaja merupakan kelompok manusia yang penuh potensi, penuh semangat patriotik, dan sebagai penerus takmir masjid dalam rangka menjaga keberlangsungan aktivitas serta produktivitas masjid.

Dengan melihat kondisi sekarang ini, anak-anak disibukkan dengan hal-hal yang berkaitan kehidupan duniawi membuat mereka lalai dan lupa akan kewajiban-kewajiban yang harus dipenuhi oleh umat muslim untuk menuju kehidupan yang abadi. Melihat keberadaan para remaja yang berada di sekitar daerah masjid Ar-Rahman juga salah satu hal yang sangat memperhatikan, maka pembinaan dan pengajaran Al-Quran di Masjid Arrahman ini dilakukan pada setiap setelah Shalat magrib menjelang Shalat isya yaitu malam Selasa, Rabu, dan Kamis merupakan hal sangat penting diharapkan nantinya remaja masjid selain menjaga keberlangsungan masjid melainkan diharapkan juga mampu mengurangi, meredam, melindungi remaja dari pengaruh-pengaruh negatif akibat adanya era globalisasi khususnya di lingkungan Masjid Ar-Rahman Kelurahan Sungai Beringin Tembilahan

\section{METODE}

Tujuan pembinaan Al-Quran ini adalah:

1. Untuk mengetahui program pembinaan remaja Masjid yang berada di kelurahan Sungai Beringin,

2. Untuk mengetahui peran remaja Masjid yang berada di kelurahan Sungai Beringin

3. Untuk mengetahui faktor pendukung dan penghambat tentang pembinaan membaca Al-Quran remaja Masjid yang berada di kelurahan Sungai Beringin, 4. Untuk mengetahui bagaimana kualitas bacaan Al-Quran remaja Masjid yang berada di kelurahan Sungai Beringin. Mengenai metode yang digunakan dalam pembinaan Al-Quran adalah metode tazkirah.

Metode yang digunakan dalam pembinaan dan pengajaran Al-Quran adalah model tadzkirah. Model tazkirah diartikan sebagai kerangka konseptual yang digunakan sebagai pedoman dalam melakukan suatu kegiatan. (Majid dan Andayani, 2011:115). 
1. Model Tadzkirah secara etimologi "Tadzkirah" berasal dari bahasa Arab yaitu "dzakkara" yang artinya ingat, dan tadzkirah artinya peringatan. Banyak sekali dijumpai di dalam AlQuran yang berkenaan dengan kalimat tadzkirah ini, diantaranya yaitu:

Artinya: "Dan tetaplah memberi peringatan, karena sesungguhnya peringatan itu bermanfaat bagi orangorang beriman." (Q.S. Al-Dzariyat: $55)$.

Model Tadzkirah secara terminologi (istilah) adalah sebuah model pembelajaran yang diturunkan dari sebuah teori pendidikan Islam. yang bermakna:

a. Teladan; Konsep keteladanan ini sudah diberikan dengan cara Allah mengutus Nabi SAW. Untuk menjadi panutan yang baik bagi umat Islam di setiap masa dan tempat. (Aedy, 2006, hlm. 106)

b. Arahkan; secara bertahap dengan melihat kemampuan yang dimiliki anak untuk kemudian ditingkatkan perlahan-lahan.

c. Dorongan; Dorongan atau pemberian motivasi yang diberikan dalam proses pertumbuhan dan perkembangan agar tidak lekas merasa bersalah, rendah diri bahkan frustrasi ketika menuai hambatan dan kegagalan. (Amirullah, 2015. hlm. 78)

d. Zakiyah; Konsep nilai kesucian diri, keikhlasan ini guru mempunyai peran penting untuk senantiasa memasukkan nilai-nilai batiniah kepada anak dalam proses pembelajaran. e. Kontinuitas; Proses pembiasaan dimulai dan ditanamkan kepada anak sejak dini, maka anak tidak akan merasa berat lagi untuk belajar.

f. Ingatkan; Dalam proses pembelajaran, seorang guru harus berusaha untuk mengingatkan kepada anak bahwa mereka senantiasa diawasi dalam belajar sehingga potensialitas menuju aktualitas.

g. Repitisi; Pendidikan yang efektif dilakukan dengan berulang kali sehingga anak menjadi mengerti.

h. Organisasikan; Guru harus mampu mengorganisasikan pengetahuan dan pengalaman yang sudah diperoleh anak di luar sekolah dengan pengalaman belajar yang diberikan.

i. Guru hendaknya membangkitkan dan membimbing kekuatan spiritual yang ada pada muridnya, sehingga hatinya akan tetap bening dan bersih. (Majid \& Andayani, hlm. 39)

2. Implementasi Model Tadzkirah Pembelajaran Al-Quran

Secara singkat implementasi model tazkirah ini menekankan dalam proses pembelajaran pada aspek:

a. Pemberian contoh keteladanan kepada siswa. Siswa memiliki sifat meniru sebagai bawaan. Peneladanan ada dua macam, peneladanan sengaja dan tidak sengaja. Termasuk dalam keteladanan sengaja seperti memberi contoh Shalat yang benar, keteladanan yang tidak sengaja seperti keteladanan dalam 
keilmuan, keikhlasan dan lainlain.

b. Pemberian arahan oleh guru kepada siswa. Arahan bertujuan agar siswa tidak mengalami kesulitan selama proses pembelajaran. Termasuk dalam arahan adalah pemberian motivasi.

c. Pembiasaan dalam proses pembelajaran. Pembiasaan dapat dilakukan untuk pembinaan sikap. Selain pembinaan sikap. Seperti pembiasaan membaca doa.

d. Pengulangan dalam proses pembelajaran. Pengulangan hampir sama dengan pembiasaan, namun pengulangan dapat dilakukan dengan bertujuan untuk memahamkan siswa terhadap materi pembelajaran.

e. Menumbuhkan kecintaan terhadap agama Islam. Tadzkirah ingin membuat siswa merasa bahwa belajar agama terutama pelajaran Al-Quran menyenangkan dan bermanfaat untuk dipelajari.

f. Mengambil hikmah dan pelajaran dari suatu materi mata pelajaran. Pelajaran (ibrah) hanya bisa dicapai oleh orang yang berpikir dengan akal dan hatinya.

3. Tahapan Implementasi Model Pembelajaran Tadzkirah

Berdasarkan beberapa teori di atas, maka dapat disimpulkan bahwa tahapan-tahapan model pembelajaran Tadzkirah sebagai berikut: Menurut Ahmad Zayadi dan Abdul Majid dan Abdul Majid dan Dian Andayani, langkah-langkah pembelajaran dengan menerapkan model Tadzkirah adalah. (Majid \& Andayani, 2011, hlm. 148-149).

a. Tahap pertama

1) Mengidentifikasi dan mendefinisikan perilaku yang menjadi sasaran.

2) Merumuskan secara khusus perilaku akhir

3) Mengembangkan rencana untuk mengukur dan mencatat perilaku.

b. Tahap kedua: Menetapkan posisi Para pelajar menimbang-nimbang posisi atau kedudukannya. Kemudian menyatakan kedudukannya dalam perilaku itu dan dalam hubungannya dengan konsekuensi dari perilaku itu.

1) Menetapkan titik di mana terlihat adanya perusakan perilaku atas dasar data yang diperoleh

2) Membuktikan konsekuensi yang diinginkan dan tidak diinginkan dari posisi yang dipilih

3) Menjernihkan konflik perilaku dengan melakukan proses uswah dan perumpamaan.

c. Tahap ketiga: Menetapkan prioritas

1) Menetapkan prioritas dengan cara membandingkan perilaku yang satu dengan yang lain.

2) Para pelajar menyatakan prioritas tersebut dalam perilaku keseharian.

d. Tahap keempat: Menjernihkan dan menguji kedudukan siswa

1) Para pelajar menyatakan dan memberikan rasional tentang 
perilaku yang telah pembelajaran bahwa masih ditemukannya dilaksanakan. sejumlah hambatan bentuk yang mendasar

2) Guru menjernihkan konflik nilai dari perilaku yang telah dilaksanakan pelajar.

e. Tahap kelima: Retensi dan reinforcement

1) Para pelajar meluruskan belum maksimal dalam pengucapan huruf hijaiah baik berdasarkan ilmu tajwid maupun dari segi kefasihan membaca AlQuran.

Pembiasaan dalam proses perilakunya dalam situasi yang berbeda.

2) Guru menganalisis kemajuan dan proses yang dilakukan siswa dan terus menerus memberikan kesadaran.

3) Tahap keenam: Penilaian otentik Guru menetapkan konsekuensi yang diperkirakan dan menguji kesahihan faktual dari perilaku yang ditentukan di awal kegiatan.

\section{HASIL DAN PEMBAHASAN}

Pembinaan dan pembelajaran AlQuran dengan metode tazkirah di Masjid Ar-Rahman diperoleh gambaran bahwa, keteladanan seorang guru terhadap remaja Masjid Ar-Rahman memberikan dampak yang nyata yaitu akan mudah menggugah, mempengaruhi remaja untuk lebih giat belajar Al-Quran dan berusaha menciptakan perilaku yang baik dalam pribadinya tentang adab mempelajari AlQuran. Selain keteladanan guru senantiasa memberikan berupa arahan kepada remaja masjid. Arahan bertujuan agar remaja masjid tidak mengalami kesulitan selama proses pembelajaran, kesulitan belajar di mana remaja kurang mampu menghadapi tuntutan-tuntutan yang harus dilakukan dalam proses pembelajaran. Dalam pembelajaran ini salah satu cara yang terapkan terhadap remaja dalam mempelajari Al-Quran seperti berwudu menyentuh mushaf, berdoa sebelum membaca Al-Quran, membaca dengan perlahan-lahan, berdoa sebelum akhir dari pada pembelajaran. Pembiasaan ini secara langsung maupun tidak langsung secara perlahan akan terdorong bagi diri remaja keinginan untuk mengadakan pengulangan dalam proses pembelajaran. Pengulangan hampir sama dengan pembiasaan, namun pengulangan dapat dilakukan dengan bertujuan untuk memahamkan siswa terhadap materi pembelajaran. Cara pengulangan ini tujuannya agar pelajaran yang telah diterima melekat dalam ingatan, tujuan lainnya adalah melatih daya-daya yang ada pada manusia yang terdiri atas daya mengamati, menanggap, mengingat, mengkhayal, merasakan, berpikir.

Kelanjutan dari pengulangan dan pembiasaan terhadap pembinaan dan pembelajaran Al-Quran bagi remaja masjid berhasil menumbuhkan kecintaan untuk mempelajari Al-Quran. Hal ini ditandai dengan adanya remaja merasa bahwa belajar agama terutama pelajaran Al-Quran menyenangkan dan bermanfaat untuk dipelajari. Bahkan lebih jauh bagi remaja Masjid ingin mempelajari hikmah dan pelajaran dari suatu ayat Al-Quran. 


\section{SIMPULAN}

Pembinaan remaja Masjid dalam mempelajari Al-Quran melalui metode tazkirah di masjid Ar-Rahman Parit 17. Kelurahan Sungai Beringin Kecamatan Tembilahan Kabupaten Indragiri hilir. Pembinaannya mampu menumbuhkan terhadap kepribadian remaja Masjid ArRahman menumbuhkan rasa cinta terhadap Al-Quran hal ini dibuktikan, walaupun mereka belum sepenuhnya mampu membaca Al-Quran dengan fasih berdasarkan ilmu tajwid, namun tidak pernah timbul perasaan bosan dalam belajar Al-Quran apalagi sampai perasaan ingin berhenti mempelajari Al-Quran, bahkan diantara mereka $70 \%$ sangat berkeinginan untuk terus mempelajari AlQuran sampai kepada tingkat pemahaman makna serta kandungannya. Karena itu pembinaan Al-Quran yang dilaksanakan di Masjid Ar-Rahman Parit 17 Kelurahan Sungai Beringin Kecamatan Tembilahan kabupaten Indragiri Hilir cukup berhasil dan perlu dilanjutkan.

\section{DAFTAR PUSTAKA}

Aedy, H. (2006). Karya Agung Sang Guru Sejati. Bandung: Alfabeta.

Amirullah, A (2015). Teori Pendidikan Karakter Remaja Dalam Keluarga. Bandung: Alfabeta

Departemen Agama RI Al-Hikmah. (2008). Yayasan Penyelenggara Penerjemah Al-Quran, Al-Quran dan Terjemahnya, Bandung: Diponegoro

Majid, A., \& Andayani, D. (2011). Pendidikan Karakter Perspektif Islam. Bandung: Remaja Rosdakarya 